\title{
TRES VIENTOS
}

\section{CHerguI}

Mala fortuna, presagia el meteorólogo que se derrite en un televisor de bulbos rancios como flores muertas, para aquel que salga de su lecho cuando el fuego se presente en todo su esplendor. Sean mansos y quédense tranquilos, acorten la distancia entre los cuerpos lenta, antiguamente, sigan los protocolos del sudor que brota en torpes llamaradas del más profundo mediodía. Cierren postigos y persianas, hagan del dormitorio un espasmo bermellón donde el Sahara se desdoble sin riesgo de acabar con los oasis.

Beban agua, aljibes, charcas, océanos enteros, saliven con recelo en los poros, los pozos insondables de la piel: no agoten, por Alá, los líquidos secretos que la aurora ha develado con tanta precaución.

Busquen el sueño o al menos el ensueño en manos del marido inclemente, la esposa de carnes eclipsadas, el púber pródigo en caricias, la doncella que merca con visiones: 
la vigilia de la razón produce monstruos, puñales dispuestos a azuzar al asesino que todos criamos dentro.

No se dejen contagiar por la fiebre del anciano que en el cuarto de al lado, el clima inhóspito de al lado, jadea a punto de ingresar en un cementerio de elefantes: pásense la lengua por los labios, humedezcan sus retinas con las gotas de una pesadilla apenas recordada. Piensen en el Rif como si fuera una mujer que arde y se revuelca bajo el cielo marroquí, imaginen un muñón en lugar del peñón de Gibraltar: el brazo de un titán cortado de cuajo por el soplo de un viento vuelto soplete furibundo. Mala, pésima fortuna, pronuncia el augur televisivo bajo las aspas del ventilador que gira con la seductora languidez del áspid, para aquel que rete a duelo al chergui: cien, mil años de locura traerá siempre la flama en su regazo. 